\title{
PHYCOCYANIN PRODUCTION IN SEAWATER CULTURE OF Arthrospira maxima
}

\section{PRODUCCIÓN DE FICOCIANINA EN CULTIVOS DE Arthrospira maxima EN AGUA DE MAR}

\author{
Teresa Lamela \\ Facundo J. Márquez-Rocha* \\ Departamento de Biotecnología Marina \\ Centro de Investigación Científica y de Educación Superior de Ensenada (CICESE) \\ Apartado postal 2732 \\ Ensenada, C.P. 22830, Baja California, México \\ *E-mail: fmarquez@ cicese.mx
}

Recibido en octubre de 1999; aceptado en agosto de 2000

\begin{abstract}
ABTRACT
Three seawater-based media were used for biomass and phycocyanin production by Arthrospira maxima. Among the three seawater-based media, growth rate and biomass were lowest in SWMAB, which is identical to SWM but includes several known essential elements ( $\mathrm{Zn}, \mathrm{Cu}, \mathrm{Mo}, \mathrm{Mn})$. Growth in SWMX2, which has double the concentration of $\mathrm{NaHCO}_{3}, \mathrm{~N}, \mathrm{P}$ and FeEDTA than SWM, was not significantly different. Arthrospira maxima reached a biomass concentration of $2.7 \pm 0.06 \mathrm{~g} \mathrm{~L}^{-1}$ in a mineral standard medium, but $<1.2 \pm 0.09 \mathrm{~g} \mathrm{~L}^{-1}$ in the seawater-based media. Pigment content in cells grown in the seawater-based media was $<2.78 \pm 0.46,<1.85 \pm 0.18$ and $<19.83 \pm 3.16 \mathrm{mg} \mathrm{g}^{-1}$ cell for chlorophyll $a$, carotenoids and phycocyanin, respectively. The phycocyanin produced in the seawater-based media had slightly different absorption and fluorescence maxima compared to those of A.platensis .
\end{abstract}

Key words: Arthrospira maxima, phycocyanin, pigments, seawater culture.

\section{RESUMEN}

Tres medios de cultivo preparados en agua de mar fueron usados para la producción de biomasa y ficocianina por Arthrospira maxima. Entre los tres medios preparados en agua de mar, la tasa de crecimiento y la biomasa fueron los más bajos en SWMAB, el cual es idéntico a SWM, pero incluye varios elementos esenciales conocidos ( $\mathrm{Zn}, \mathrm{Cu}, \mathrm{Mo}, \mathrm{Mn})$. El crecimiento en SWMX2, el cual tiene el doble de concentración de $\mathrm{NaHCO}_{3}, \mathrm{~N}, \mathrm{P}$ y FeEDTA que SWM, no fue significativamente diferente para estos dos medios. Arthrospira maxima alcanza una concentración de biomasa de $2.7 \pm 0.06 \mathrm{~g} \mathrm{~L}^{-1}$ en un medio mineral estándar, pero $<1.2 \pm 0.09 \mathrm{~g} \mathrm{~L}^{-1}$ en los medios preparados en agua de mar. El contenido de pigmentos en células crecidas en los medios preparados en agua de mar fue de $<2.78 \pm 0.46$, $<1.85 \pm 0.184$ y $<19.83 \pm 3.16 \mathrm{mg} \mathrm{g}^{1}$ células para clorofila $a$, carotenoides y ficocianina, 
Ciencias Marinas, Vol. 26, No. 4, 2000

respectivamente. La ficocianina producida en los medios preparados en agua de mar mostró leves diferencias en sus propiedades espectrales de absorción y fluorescencia máxima comparadas con las de A.platensis .

Palabras clave: Arthrospira maxima, ficocianina, pigmentos, cultivo en agua de mar.

\section{INTRODUCTION}

Baja California is a semi-arid state located on the Mexican Pacific coast. This area has a deficiency of fresh water; however, it has favorable climatic conditions for the outdoor mass culture of some microalgae, particularly Arthrospira sp. (previously Spirulina sp.) (Castenholtz, 1994). Arthrospira produces a blue pigment of high economic value, used as a food additive, as a cosmetic colouring agent (Cysewski, 1992), as biomarkers (Herrera et al., 1989), and in cancer laser therapy (Cai et al., 1995).

It is known that some strains of Arthrospira maxima can grow in different seawater media with reduced production costs (Materassi et al., 1984; Tredici et al., 1986; Wu et al., 1993; Olguín et al., 1994, 1997). However, several physiological aspects of growth in seawater remain unknown (Materassi et al., 1984) and little information about phycocyanin production in seawater culture is available.

The blue pigment, phycocyanin, consists of a protein moiety ( $\alpha$ and $\beta$ apoprotein subunits) with bilin-type chromophores. Phycocyanin accounts for about $30 \%$ of the biomass (Garnier and Thomas, 1993), but its concentration in the cell depends on environmental growth conditions (Márquez et al., 1995; Márquez-Rocha, 1999). Phycocyanin is generally believed to be an accessory pigment that captures light energy and transfers it to chlorophyll $a$. Several authors have suggested that phycocyanin may also function as a carbon storage material (Miller and Holt, 1977), or as a nitrogen source during nitrogen starvation (Boussiba and Richmond, 1980). The aim of

\section{INTRODUCCIÓN}

Baja California es un estado semi-desértico localizado en la costa del Pacífico mexicano. Esta área tiene deficiencia de agua dulce; sin embargo, tiene condiciones climáticas favorables para el cultivo a cielo abierto de algunas microalgas, particularmente de Arthrospira sp. (anteriormente Spirulina sp.) (Castenholtz, 1994). Arthrospira produce un pigmento azul de alto valor económico, usado como un aditivo alimentario, como agente colorante para cosméticos (Cysewski, 1992), como biomarcador (Herrera et al., 1989) y en la terapia de láser para cáncer (Cai et al., 1995).

Es conocido que algunas cepas de Arthrospira maxima pueden crecer en diferentes medios con agua de mar, reduciendo los costos de producción (Materassi et al., 1984; Tredici et al., 1986; Wu et al., 1993; Olguín et al., 1994, 1997). Sin embargo, varios aspectos fisiológicos de crecimiento en agua de mar son desconocidos (Materassi et al., 1984) y hay poca información disponible acerca de la producción de ficocianina en cultivos con agua de mar.

El pigmento azul, ficocianina, consiste de una composición proteica (subunidades de apoproteína $\alpha$ y $\beta$ ) con cromóforos tipo bilina. La ficocianina alcanza cerca de $30 \%$ de la biomasa (Garnier y Thomas, 1993), pero su concentración en la célula depende de las condiciones ambientales de crecimiento (Márquez et al., 1995; Márquez-Rocha, 1999). Se ha creído generalmente que la ficocianina es un pigmento accesorio que captura la energía luminosa y la transfiere a la clorofila $a$. Varios autores han sugerido que la ficocianina puede funcionar 
the present study was to evaluate phycocyanin production and its biochemical characteristics, using seawater-based media for the cultivation of A. maxima.

\section{MATERIALS AND METHODS}

\section{Organism and growth conditions}

The A. maxima strain from the culture collection of the Centro de Investigación Científica y de Educación Superior de Ensenada (CICESE) was grown in $80 \mathrm{~mL}$ glass tubes (30 $\mathrm{mm}$ diameter) that were arranged on a special rack with four lateral fluorescent lamps (General Electric, F96T2-D-EX, daylight). The cultures, under continuous illumination $\left(230 \mu \mathrm{mol}\right.$ photon $\mathrm{m}^{-2} \mathrm{~s}^{-1}$ on the surface $)$ were bubbled with filtered air and shaken manually once a day to maintain homogeneous conditions. The inoculum was cultivated in $250 \mathrm{~mL}$ Erlenmeyer flasks containing $100 \mathrm{~mL}$ of mineral standard medium at $23^{\circ} \mathrm{C}$, on a rotary shaker, until the culture reached an absorbance of $0.5 \mathrm{OD}_{560} \mathrm{~nm}$. This strain was adapted to growth on seawater for three generations before its use in these experiments and the cultures were inoculated at the same biomass concentration $\left(10 \%, \mathrm{OD}_{560}=0.5\right)$. Before inoculation, cells were centrifuged and washed with distilled water to eliminate any medium cross-contamination.

\section{Culture media}

Mineral standard medium (SOT) described by Ogawa and Terui (1970) was used as control and three different media prepared with seawater were tested (table 1). The SOT medium is well suited for laboratory cultures of Arthrospira, but it is too elaborate and expensive for outdoor mass cultivation. Seawater was obtained from the seawater distribution system used for aquaculture research at our como material de almacenamiento de carbono (Miller y Holt, 1977) o como una fuente de nitrógeno durante la inanición de nitrógeno (Boussiba y Richmond, 1980). El propósito del presente estudio fue el de evaluar la producción de ficocianina y sus características bioquímicas, usando medios preparados en agua de mar para el cultivo de A. maxima.

\section{MATERIALES Y MÉTODOS}

\section{Organismo y condiciones de crecimiento}

La cepa A. maxima de la colección de cultivos del Centro de Investigación Científica y de Educación Superior de Ensenada (CICESE) fue crecida en tubos de vidrio de $80 \mathrm{~mL}$ (30 mm de diámetro), que fueron colocados en un estante especial con cuatro lámparas fluorescentes laterales (General Electric, F96T2-D-EX, Daylight). Los cultivos con iluminación continua $\left(230 \mu \mathrm{mol}\right.$ photon $\mathrm{m}^{2} \mathrm{~s}^{-1}$ sobre la superficie) fueron burbujeados con aire filtrado y agitados manualmente una vez al día para mantener las condiciones homogéneas. El inóculo fue cultivado en matraces Erlenmeyer de $250 \mathrm{~mL}$, conteniendo $100 \mathrm{~mL}$ de medio estándar mineral a $23^{\circ} \mathrm{C}$, en un agitador rotatorio, hasta que el cultivo alcanzara una absorbancia de $0.5 \mathrm{OD}_{560} \mathrm{~nm}$. Esta cepa fue adaptada a crecer en agua de mar por tres generaciones antes de usarse en los experimentos y los cultivos fueron inoculados a la misma concentración de biomasa $\left(10 \%, \mathrm{OD}_{560}=0.5\right)$. Antes de la inoculación, las células fueron centrifugadas y lavadas con agua destilada para eliminar cualquier contaminación cruzada del medio.

\section{Medio de cultivo}

El medio mineral estándar (SOT) descrito por Ogawa y Terui (1970) fue usado como control y tres diferentes medios preparados con agua de mar fueron probados (tabla 1). El 
Ciencias Marinas, Vol. 26, No. 4, 2000

Table 1. Element composition of the culture media used for the cultivation of Arthrospira maxima.

Tabla 1. Composición de elementos de los medios usados para el cultivo de Arthrospira maxima.

\begin{tabular}{lcccc}
\hline Component & $\begin{array}{c}\text { SOT } \\
\left(\mathrm{g} \mathrm{L}^{-1}\right)\end{array}$ & $\begin{array}{c}\mathrm{SWM} \\
\left(\mathrm{g} \mathrm{L}^{-1}\right)\end{array}$ & $\begin{array}{c}\text { SWMAB } \\
\left(\mathrm{g} \mathrm{L}^{-1}\right)\end{array}$ & $\begin{array}{c}\text { SWMX2 } \\
\left(\mathrm{g} \mathrm{L}^{-1}\right)\end{array}$ \\
\hline $\mathrm{NaHCO}_{3}$ & 16.8 & 0.1 & 0.1 & 0.2 \\
$\mathrm{~K}_{2} \mathrm{HPO}_{4}$ & 0.5 & $0.008^{*}$ & $0.008^{*}$ & $0.016^{*}$ \\
$\mathrm{NaNO}_{3}$ & 2.5 & 1.0 & 1.0 & 2.0 \\
$\mathrm{~K}_{2} \mathrm{SO}_{4}$ & 1.0 & - & - & - \\
$\mathrm{NaCl}$ & 1.0 & - & - & - \\
$\mathrm{MgSO}_{4} \cdot 7 \mathrm{H}_{2} \mathrm{O}$ & 0.2 & - & - & - \\
$\mathrm{CaCl}_{2} \cdot 2 \mathrm{H}_{2} \mathrm{O}$ & 0.04 & - & - & - \\
$\mathrm{FeSO}_{4} \cdot 7 \mathrm{H}_{2} \mathrm{O}$ & 0.01 & - & - & - \\
$\mathrm{Na}_{2} \mathrm{EDTA}$ & 0.08 & - & - & - \\
$\mathrm{FeEDTA}$ & - & 0.005 & 0.005 & 0.01 \\
$\mathrm{~A}_{5}$ & $1 \mathrm{~mL} \mathrm{~L}$ & - & $1 \mathrm{~mL} \mathrm{~L}^{-1}$ & - \\
$\mathrm{B}_{6}$ & $1 \mathrm{~mL} \mathrm{~L}$ & - & $1 \mathrm{~mL} \mathrm{~L}^{-1}$ & - \\
$\mathrm{pH}$ (initial) & 9.49 & 8.49 & 8.43 & 8.45 \\
\hline
\end{tabular}

campus facilities. The three seawater-based media were autoclaved (natural seawater has a salinity of $35 \%$ and $\mathrm{pH}$ 8.39). Details of media composition are given in table 1 . Cultures were grown for six days at $23^{\circ} \mathrm{C}$, in triplicate. The initial $\mathrm{pH}$ depends on the culture medium and varied between 9.4 and 9.49 in the SOT medium and between 8.4 and 8.5 in the seawater media (table 1). Solution $\mathrm{A}_{5}$ contains $\left(\mathrm{gL}^{-1}\right): \mathrm{H}_{3} \mathrm{BO}_{3} 2.85, \mathrm{MnCl}_{4} \cdot \mathrm{H}_{2} \mathrm{O} \quad 1.81$, $\mathrm{ZnSO}_{4} .7 \mathrm{H}_{2} \mathrm{O} 0.22, \mathrm{CuSO}_{4} .5 \mathrm{H}_{2} \mathrm{O}$ and $\mathrm{MoO}_{3}$ 0.015 . Solution $\mathrm{B}_{6}$ contains $\left(\mathrm{mg} \mathrm{L}^{-1}\right)$ : $\mathrm{NH}_{4} \mathrm{VO}_{3}$ $23, \mathrm{~K}_{2} \mathrm{Cr}_{2}\left(\mathrm{SO}_{4}\right)_{4} \cdot 24 \mathrm{H}_{2} \mathrm{O} 96, \mathrm{NiSO}_{4} \cdot 7 \mathrm{H}_{2} \mathrm{O} 48$, $\mathrm{NaWO}_{4} \cdot 2 \mathrm{H}_{2} \mathrm{O} \quad 18, \quad \mathrm{Ti}_{2}\left(\mathrm{SO}_{4}\right)_{3} \quad 40$, $\mathrm{Co}\left(\mathrm{NO}_{3}\right)_{2} \cdot 6 \mathrm{H}_{2} \mathrm{O} 44$ (Ogawa and Terui, 1970). medio SOT es el adecuado para el crecimiento en el laboratorio de cultivos de Arthrospira, pero es muy elaborado y caro para cultivo masivo a cielo abierto. El agua de mar se obtuvo del sistema de distribución usado para investigaciones en acuacultura dentro de nuestro campus. Los tres medios basados en agua de mar fueron esterilizados (agua de mar natural tiene una salinidad de $35 \%$ y un $\mathrm{pH}$ de 8.39). Los detalles de la composición de los medios se dan en la tabla 1 . Los cultivos fueron crecidos por seis días a $23^{\circ} \mathrm{C}$, por triplicado. El $\mathrm{pH}$ inicial depende del cultivo y varía de 9.4 a 9.49 en el medio SOT y de 8.4 a 8.5 en el medio con agua de mar (tabla 1). La solución $\mathrm{A}_{5}$ está compuesta de $\left(\mathrm{g} \mathrm{L}^{-1}\right): \mathrm{H}_{3} \mathrm{BO}_{3}$ 2.85, 


\section{Dry weight determination and pigment analyses}

Growth was determined either by measuring optical density at $560 \mathrm{~nm}$ or by dry weight of cells after filtration on cellulose nitrate filters $(0.45 \mu \mathrm{m})$, followed by overnight drying at $105^{\circ} \mathrm{C}$. To estimate pigments, cells were harvested by centrifugation $(2500 \mathrm{~g}$, 15 minutes), washed with distilled water and frozen at $-20^{\circ} \mathrm{C}$ for subsequent analyses. Chlorophyll $a$ and carotenoids were extracted from the cell suspension with $90 \% \quad(\mathrm{v} / \mathrm{v})$ methanol at $4^{\circ} \mathrm{C}$ in dim light. Several extractions followed by sonication and centrifugation were carried out until total pigment recovery. The chlorophyll content in the biomass was calculated from the absorbance at $665 \mathrm{~nm}$ of the methanolic extract $\left(\mathrm{OD}_{665} \times 13.9 \mu \mathrm{g} \mathrm{mL}^{-1}\right)$ (Tandeu and Houmard, 1988). The total carotenoid content was determined from the methanolic extract at $480 \mathrm{~nm}$ using $\mathrm{A}_{1 \%}=2500$ as the absorption coefficient (Chapman, 1988). For the determination of intracellular phycocyanin the cells were first disrupted by sonication and frozen in $0.1 \mathrm{M}$ Na-phosphate buffer $(\mathrm{pH} 7)$. After thawing at room temperature and centrifugation (2500 rpm, 15 minutes) the total phycocyanin (PC) concentration in the supernatant was calculated from the absorbances at 615 and $652 \mathrm{~nm}$ according to the following equation: $\mathrm{PC}=\left(\mathrm{OD}_{615}-0.0 .474\left(\mathrm{OD}_{652}\right)\right) / 5.34$ (Benett and Bogard, 1973).

The crude extract containing phycocyanin was precipitated in 50\% $\left(\mathrm{NH}_{4}\right)_{2} \mathrm{SO}_{4}$ and recovered by centrifugation at $10,000 \mathrm{xg}$ for 10minutes. The colourless, clear supernatant was discarded and the blue precipitate wasdissolved in a small volume of $0.0025 \mathrm{M}$ Na-phosphate buffer ( $\mathrm{pH}$ 7.0) and dialyzed against the same buffer.

The dialyzed phycocyanin was then placed in a $2.5 \times 30 \mathrm{~cm}$ hydroxylapatite column and two main fractions were pooled. Following
$\mathrm{MnCl}_{4} \cdot \mathrm{H}_{2} \mathrm{O} \quad 1.81, \quad \mathrm{ZnSO}_{4} \cdot 7 \mathrm{H}_{2} \mathrm{O} \quad 0.22$, $\mathrm{CuSO}_{4} .5 \mathrm{H}_{2} \mathrm{O}$ y $\mathrm{MoO}_{3}$ 0.015. La solución $\mathrm{B}_{6}$ está compuesta de $\left(\mathrm{mg} \mathrm{L}^{-1}\right): \mathrm{NH}_{4} \mathrm{VO}_{3} \quad 23$, $\mathrm{K}_{2} \mathrm{Cr}_{2}\left(\mathrm{SO}_{4}\right)_{4} \cdot 24 \mathrm{H}_{2} \mathrm{O} \quad 96, \quad \mathrm{NiSO}_{4} \cdot 7 \mathrm{H}_{2} \mathrm{O} \quad 48$, $\mathrm{NaWO}_{4} \cdot 2 \mathrm{H}_{2} \mathrm{O} \quad 18, \quad \mathrm{Ti}_{2}\left(\mathrm{SO}_{4}\right)_{3} \quad 40$, $\mathrm{Co}\left(\mathrm{NO}_{3}\right)_{2} \cdot 6 \mathrm{H}_{2} \mathrm{O} 44$ (Ogawa y Terui, 1970).

\section{Determinación del peso seco y análisis de pigmentos}

El crecimiento fue determinado por densidad óptica a $560 \mathrm{~nm}$ o por el peso seco de las células después de filtrarlas a través de filtros de nitrato de celulosa $(0.45 \mu \mathrm{m})$, seguidas por secado toda la noche a $105^{\circ} \mathrm{C}$. Para estimar los pigmentos, las células fueron cosechadas por centrifugación (2500 g, 15 minutos), lavadas con agua destilada y congeladas a $-20^{\circ} \mathrm{C}$ para subsecuentes análisis. La clorofila $a$ y los carotenoides fueron extraídos de la suspensión celular con $90 \%(\mathrm{v} / \mathrm{v})$ metanol a $4^{\circ} \mathrm{C}$ en luz tenue. Varias extracciones fueron seguidas por sonicación y centrifugación hasta la recuperación total de pigmentos. El contenido de clorofila en la biomasa fue calculado de la absorbancia a $665 \mathrm{~nm}$ del extracto metanólico $\left(\mathrm{OD}_{665} \times 13.9 \mu \mathrm{g} \mathrm{mL}^{-1}\right)$ (Tandeu y Houmard, 1988). El contenido total de carotenoides fue determinado del extracto metanólico midiendo a $480 \mathrm{~nm}$, usando $\mathrm{A}_{1 \%}=2500$ como coeficiente de absorción (Chapman, 1988). Para la determinación intracelular de ficocianina las células fueron sonicadas y congeladas en un amortiguador (pH7). Después de descongelar a temperatura ambiente y centrifugar (2500 rpm, 15 minutos), la concentración de ficocianina total (PC) en el sobrenadante fue calculada de las absorbancias a 615 y $652 \mathrm{~nm}$ de acuerdo con la siguiente ecuación: $\mathrm{PC}=\left(\mathrm{OD}_{615}-0.0 .474\left(\mathrm{OD}_{652}\right)\right) / 5.34$ (Benett y Bogard, 1973).

El extracto crudo que contiene a la ficocianina fue precipitado en $50 \% \quad\left(\mathrm{NH}_{4}\right)_{2} \mathrm{SO}_{4}$ y 
Ciencias Marinas, Vol. 26, No. 4, 2000

a stepwise elution with a phosphate buffer of increasing ionic strength at $\mathrm{pH} 7.0$, the $615 / 280 \mathrm{~nm}$ and $652 / 280 \mathrm{~nm}$ ratios were measured through the fractions eluted with Na-phosphate buffer from 2.5 to $100 \mathrm{mM}$. The fraction exhibiting the larger ratio $(615 / 280 \mathrm{~nm})$ was further purified by column chromatography on DEAE Sephadex A-50.

\section{RESULTS}

The biomass concentrations attained with the SOT medium and the SWM, SWMX2 and SWMAB media after six days of cultivation were $2.7 \pm 0.06,1.04 \pm 0.15,1.2 \pm 0.09$ and $0.49 \pm 0.03 \mathrm{~g} \mathrm{~L}^{-1}$, respectively. Statistical analysis revealed no significant differences between the biomass concentration obtained with SWM and SWMX2 (one-way ANOVA, Duncan test, $P<0.05$ ). Both were higher than the biomass concentration in SWMAB medium $\left(0.49 \pm 0.03 \mathrm{~g} \mathrm{~L}^{-1}\right)$, but were half of the biomass attained in SOT (table 2). Figure 1 shows the time course of biomass in the different media. The specific growth rates were $0.48 \pm 0.06,0.16 \pm 0.025,0.18 \pm 0.032$ and $0.068 \pm 0.025 \mathrm{~d}^{-1}$ for the SOT, SWM, SWMX2 and SWMAB media, respectively. Values are means \pm SD from three experiments. The initial $\mathrm{pH}$ in SOT was $9.5 \pm 0.01$ and the finalpH, reached after six days of culture, was $11.6 \pm 0.09$. The $\mathrm{pH}$ in the seawater-based media changed from 8.4 to 9.0 after six days of culture.

The seawater culture induced differences in the pigment content. After six days of culture in SOT medium, chlorophyll a content was $6.10 \pm 0.48 \mathrm{mg} \mathrm{g}^{-1}$ cell, while carotenoid content was $2.18 \pm 0.16 \mathrm{mg} \mathrm{g}^{-1}$ cell. In seawater media, the concentration of chlorophyll $a$ was $2.08-2.78 \mathrm{mg} \mathrm{g}^{-1}$ and carotenoid content was 1.56-1.85 $\mathrm{mg} \mathrm{g}{ }^{1}$ dry weight (table 2). The recuperado por centrifugación a 10,000 xg durante 10 minutos. El sobrenadante incoloro fue descartado y el precipitado azul fue disuelto en un pequeño volumen de amortiguador de fosfatos-Na $0.0025 \mathrm{M}(\mathrm{pH} 7.0)$ y dializado contra el mismo amortiguador.

La ficocianina dializada fue colocada en una columna de hidroxilapatita de $2.5 \times 30 \mathrm{~cm}$ de la cual se obtuvieron dos fracciones principales. Después de una elución en etapas con amortiguador de fosfatos aumentando la fuerza iónica a pH 7.0, las relaciones 615/280 nm y $652 / 280 \mathrm{~nm}$ fueron medidas para todas las fracciones eluidas con amortiguador de fosfatos- $\mathrm{Na}$ de 2.5 a $100 \mathrm{mM}$. Las fracciones que mostraron la relación mayor $(615 / 280 \mathrm{~nm})$ fueron purificadas con una columna de cromatografía sobre DEAE Sephadex A-50.

\section{RESULTADOS}

La concentración de biomasa lograda con el medio SOT y los medios SWM, SWMX2 y SWMAB después de seis días de cultivo fue de $2.7 \pm 0.06,1.04 \pm 0.15,1.2 \pm 0.09$ y $0.49 \pm 0.03 \mathrm{~g} \mathrm{~L}^{-1}$, respectivamente. El análisis estadístico indica que no se tuvieron diferencias significativas en la concentración de biomasa obtenida con SWM y SWMX2 (ANOVA de una vía, prueba de Duncan, $P<0.05)$. Ambos fueron superiores que la concentración de biomasa en el medio SWMAB $\left(0.49 \pm 0.03 \mathrm{~g} \mathrm{~L}^{-1}\right)$, pero fueron la mitad de la concentración alcanzada con el medio SOT (tabla 2). La figura 1 muestra el comportamiento de la biomasa en los diferentes medios. Las tasas específicas de crecimiento fueron $0.48 \pm 0.06,0.16 \pm 0.025,0.18 \pm 0.032 \mathrm{y}$ $0.068 \pm 0.025 \mathrm{~d}^{-1}$ para SOT, SWM, SWMX2 y SWMAB, respectivamente. Los valores son las medias \pm desviación estándar de tres experimentos. El pH inicial en SOT fue de $9.5 \pm 0.01$ y el $\mathrm{pH}$ final alcanzado después de seis días de cultivo fue de $11.6 \pm 0.09$. El pH en los medios 
Lamela and Márquez-Rocha: Phycocyanin production

Table 2. Biomass (dry weight) and pigment content ( $\mathrm{mg} \mathrm{g}^{-1}$ dry weight) of Arthrospira maxima after six days of cultivation.

Tabla 2. Contenido de biomasa (peso seco) y pigmentos ( $\mathrm{mg} \mathrm{g}^{-1}$ peso seco) de Arthrospira maxima después de seis días de cultivo.

\begin{tabular}{lccccc}
\hline Medium & $\begin{array}{c}\text { Biomass } \\
\left(\mathrm{g} \mathrm{L}^{-1}\right)\end{array}$ & $\begin{array}{c}\text { Phycocyanin } \\
\left(\mathrm{mg} \mathrm{g}^{-1}\right)\end{array}$ & $\begin{array}{c}\text { Chlorophyll } a \\
\left(\mathrm{mg} \mathrm{g}^{-1}\right)\end{array}$ & $\begin{array}{c}\text { Carotenoid } \\
\left(\mathrm{mg} \mathrm{g}^{-1}\right)\end{array}$ & $\begin{array}{c}\text { Growth rate } \\
\left(\mathrm{d}^{-1}\right)\end{array}$ \\
\hline SOT & $2.7 \pm 0.06$ & $45.34 \pm 4.40$ & $6.10 \pm 0.48$ & $2.18 \pm 0.16$ & 0.48 \\
SWM & $1.04 \pm 0.15$ & $18.46 \pm 0.60$ & $2.78 \pm 0.46$ & $1.85 \pm 0.18$ & 0.16 \\
SWMAB & $0.49 \pm 0.03$ & $19.83 \pm 3.16$ & $2.08 \pm 0.69$ & $1.67 \pm 0.12$ & 0.068 \\
SWMX2 & $1.2 \pm 0.09$ & $15.19 \pm 0.58$ & $2.35 \pm 0.44$ & $1.56 \pm 0.15$ & 0.18 \\
\hline
\end{tabular}

chlorophyll content in the seawater cultures was half of the content obtained with SOT; however, the carotenoid content was not significantly different (table 2) (one-way ANOVA, Duncan test, $P<0.05)$.

Phycocyanin was the major pigment fraction in all the media tested (table 2) and the content was strongly affected by the medium composition. SOT medium produced a content of $45.34 \pm 4.40 \mathrm{mg} \mathrm{g}^{-1}$ dry weight. The addition of $A_{5}$ and $B_{6}$ solutions to the seawater medium SWMAB did not enhance the phycocyanin content compared to the SWM medium (table2).

Phycocyanin from the blue-green alga $A$. maxima was purified by $\left(\mathrm{NH}_{4}\right)_{2} \mathrm{SO}_{4}$ precipitation followed by a hydroxylapatite column (fig. 2). Elution from the hydroxylapatite column of the $615 / 280 \mathrm{~nm}$ ratio (phycocyanin) was at $75 \mathrm{mM}$ Na-phosphate buffer with a yield of 3.5 , while the $652 / 280 \mathrm{~nm}$ ratio (allophycocyanin) was eluted at $100 \mathrm{mM} \mathrm{Na-phosphate.}$ After a Sephadex A-50 column, the yield for the $615 / 280 \mathrm{~nm}$ ratio was $>4$ (table 3 ). The absorption maxima for $c$-phycocyanin and allophycocyanin were 615 and $650 \mathrm{~nm}$, respectively. The fluorescence maxima (emission) were $635 \mathrm{~nm}$ for $c$-phycocyanin and $655 \mathrm{~nm}$ for preparados en agua de mar cambiaron de 8.4 a 9.0 después de 6 días de cultivo.

Los cultivos en agua de mar indujeron diferencias en el contenido de pigmentos. Después de seis días de cultivo en medio SOT el contenido de clorofila $a$ fue $6.10 \pm 0.48 \mathrm{mg} \mathrm{g}^{-1}$ cél, mientras que el contenido de carotenoides fue de $2.18 \pm 0.16 \mathrm{mg} \mathrm{g}^{-1}$ cél. En los medios con agua de mar, la concentración de clorofila $a$ fue de 2.08 a $2.78 \mathrm{mg} \mathrm{g}^{-1}$ y el contenido de carotenoides, de 1.56 a $1.85 \mathrm{mg} \mathrm{g}^{-1}$ peso seco (tabla 2). El contenido de clorofila en los cultivos en agua de mar fue la mitad del contenido obtenido con SOT; sin embargo, el contenido de carotenoides no fue significativamente diferente (tabla 2) (ANOVA de una vía, prueba de Duncan, $P<0.05)$.

La ficocianina fue la fracción mayoritaria de los pigmentos en todos los medios probados (tabla 2) y su contenido fue afectado severamente por la composición del medio. El medio SOT produce un contenido de $45.34 \pm 4.40 \mathrm{mg} \mathrm{g}^{-1}$ peso seco. La adición de las soluciones $\mathrm{A}_{5}$ y $\mathrm{B}_{6}$ al medio SWMAB no aumenta el contenido de ficocianina comparado con el medio SWM (tabla 2).

La ficocianina del alga verde-azul $A$. maxima fue purificada por precipitación con 


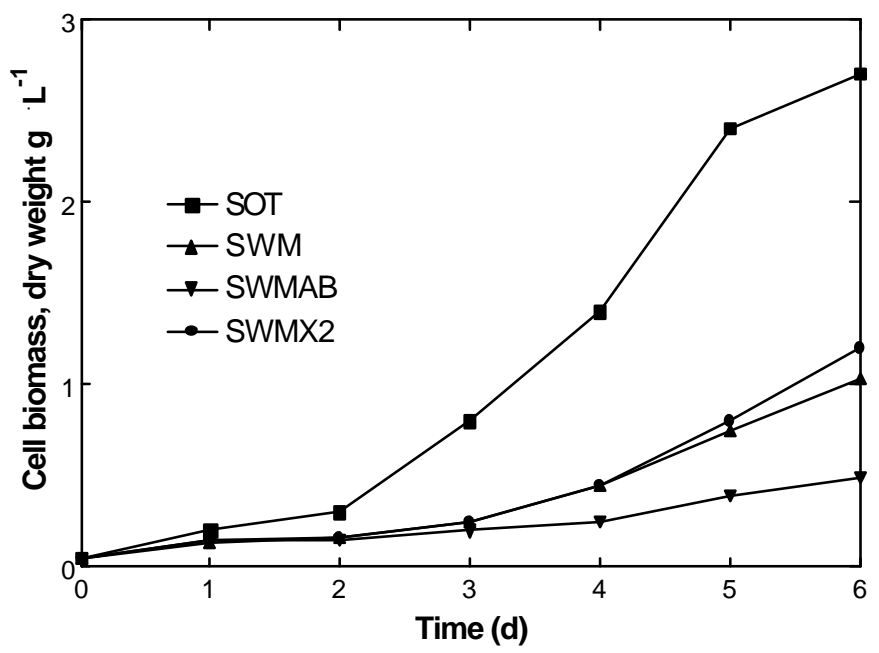

Figure 1. Autotrophic growth of Arthrospira maxima in batch culture using different media.

Figura 1. Crecimiento autotrófico del cultivo de Arthrospira maxima en lote en diferentes medios.

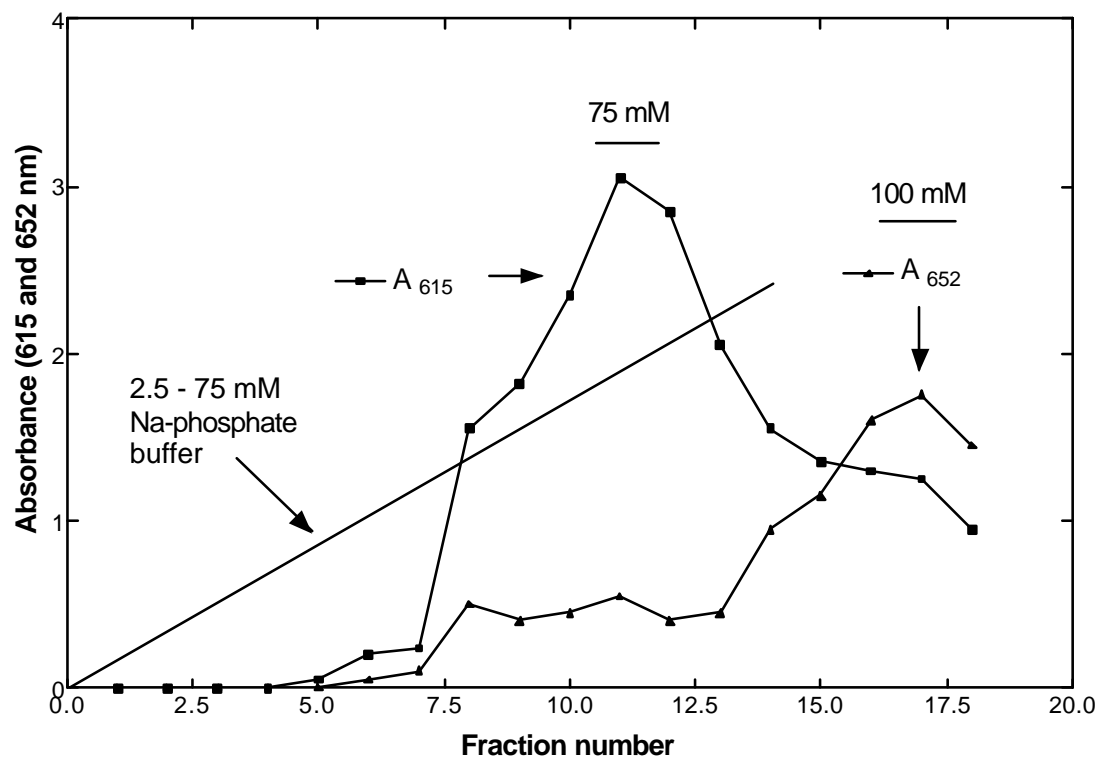

Figure 2. Chromatography of the 50\% $\left(\mathrm{NH}_{4}\right)_{2} \mathrm{SO}_{4}$ fraction (extracted from Arthrospira maxima) on hydroxylapatite.

Figura 2. Cromatografía sobre hidroxilapatita de la fracción precipitada a $50 \%\left(\mathrm{NH}_{4}\right)_{2} \mathrm{SO}_{4}$ (extraida de Arthrospira maxima). 
Table 3. Purification yields of phycocyanin from Arthrospira maxima .

Tabla 3. Rendimientos de la purificación de ficocianina de Arthrospira maxima.

\begin{tabular}{lcc}
\hline Purification step & \multicolumn{2}{c}{ Yield ratios (nm) } \\
\cline { 2 - 3 } & $615 / 280$ & $652 / 280$ \\
\hline Crude extract & 0.85 & 0.31 \\
$\left(\mathrm{NH}_{4}\right)_{2} \mathrm{SO}_{4} 50 \%$ precipitated & 1.18 & 0.50 \\
Hydroxylapatite & 2.9 & 3.5 \\
DEAE Sephadex & 4.1 & \\
\hline
\end{tabular}

Table 4. Spectral properties of the phycobiliproteins from Arthrospira maxima. $\mathrm{E}^{1 \%}{ }_{1 \mathrm{~cm}}$ : molar extinction coefficient.

Tabla 4. Propiedades espectrales de las ficobiliproteínas de Arthrospira maxima. $\mathrm{E}^{1 \%}{ }_{1 \mathrm{~cm}}$ : coeficiente de extinción molar.

\begin{tabular}{ccccc}
\hline Fraction No. & Biliprotein & $\begin{array}{c}\text { Absorption maxima } \\
(\mathrm{nm})\end{array}$ & $\begin{array}{c}\text { Fluorescence maxima } \\
(\mathrm{nm})\end{array}$ & $\mathrm{E}^{1 \%}{ }_{1 \mathrm{~cm}}$ \\
\hline 11 & $c$-phycocyanin & 615 & 635 & 71 \\
17 & allophycocyanin & 650 & 655 & 57 \\
\hline
\end{tabular}

allophycocyanin (table 4), slightly different from the 640 and $660 \mathrm{~nm}$, respectively, obtained from Spirulina platensis (Boussiba and Richmond, 1979). The absorption and fluorescence maxima resemble those reported for S. platensis (Boussiba and Richmond, 1979). The phycocyanin obtained from the halotolerant blue-green Coccochloris elabens (Kao et al., 1973) showed a molar extinction coefficient of 73 and 60 for allophycocyanin; Boussiba and Richmond (1979) found a molar extinction coefficient of 73 for phycocyanin and 58 for allophycocyanin, while in this study the molar extinction coefficient for phycocyanin was 71 and 57 for allophycocyanin. These differences may be due to speciesspecific variation or due, at least in part, to the culture conditions.
$\left(\mathrm{NH}_{4}\right)_{2} \mathrm{SO}_{4}$ seguida por una columna de hidroxilapatita (fig. 2). La elución de la columna de hidroxilapatita de la relación $615 / 280 \mathrm{~nm}$ (ficocianina) fue con amortiguador de fosfatos-Na a una concentración de $75 \mathrm{mM}$ con un rendimiento de 3.5 , mientras que la relación 652/280 nm (aloficocianina) fue eluida a una concentración de amortiguador de fosfatos$\mathrm{Na}$ de $100 \mathrm{mM}$. Después de pasar por una columna de Sephadex A-50, el rendimiento para la relación $615 / 280 \mathrm{~nm}$ fue $>4$ (tabla 3 ). La absorción máxima para $c$-ficocianina y aloficocianina fue a 615 y $650 \mathrm{~nm}$, respectivamente. La fluorescencia máxima (emisión) fue de $635 \mathrm{~nm}$ para $c$-ficocianina y de $655 \mathrm{~nm}$ para aloficocianina (tabla 4), ligeramente diferente de 640 y $660 \mathrm{~nm}$, respectivamente, que han sido obtenidas para Spirulina platensis 
Ciencias Marinas, Vol. 26, No. 4, 2000

\section{DISCUSSION}

Our data show much lower growth rates, biomass yields, chlorophyll $a$ and phycocyanin contents in A. maxima grown in seawater-based media than in the standard mineral medium, SOT. The major difference between the SOT medium and the other media is salinity, but concentrations of other components including essential nutrients $\left(\mathrm{HCO}_{3}, \mathrm{CO}_{3}, \mathrm{~N}, \mathrm{P}, \mathrm{Fe}\right)$ are also different.

Among the three seawater-based media, growth rate and biomass were lowest in SWMAB, which is identical to SWM but includes several known essential elements ( $\mathrm{Zn}$, $\mathrm{Cu}, \mathrm{Mo}, \mathrm{Mn}$ ), as well as other elements whose function in phytoplankton has not been established. Possibly, the poor growth in this medium is the result of metal toxicity, which is common when essential trace metals are added in excess. It is also curious that growth in SWMX2, which has double the content of $\mathrm{NaHCO}_{3}, \mathrm{~N}, \mathrm{P}$ and FeEDTA than SWM, was not significantly greater, suggesting that either growth was still limited by one of these nutrients or salinity was the major limiting factor.

Tredici et al. (1986) have pointed out that physiological stress induced by seawater cultures of Spirulina maxima is evidenced by a reduced rate of protein synthesis, an increase in the carbohydrate content, a massive fragmentation in the trichomes and strong reduction in the phycobiliprotein content. However, cell concentration was not very different from values obtained in fresh-water cultures.

The low growth rate obtained in our experiments in seawater-based media may be due to respiratory and excretory losses of energy to counteract the ionic and osmotic stress (Kebede, 1997). Under high light conditions, carotenoids are used by some microalgae to protect chlorophyll $a$ from photo-oxidation, but carotenoid synthesis has also been described as a response to high salinity (Kebede, 1997).
(Boussiba y Richmond, 1979). La absorción y fluorescencia máximas son muy parecidas a las reportadas para $S$. platensis (Boussiba y Richmond, 1979). La ficocianina obtenida de la alga halotolerante verde-azul Coccochloris elabens (Kao et al., 1973) muestra coeficientes de extinción molar de 73 y 60 para aloficocianina; Boussiba y Richmond (1979) encontraron un coeficiente de extinción molar de 73 para ficocianina y 58 para aloficocianina, mientras que en este estudio el coeficiente de extinción molar para ficocianina fue de 71 y 57 para aloficocianina. Estas diferencias pueden deberse a las variaciones especie-específicas o, al menos en parte, a las condiciones del medio de cultivo.

\section{DISCUSIÓN}

Nuestros datos muestran menores tasas de crecimiento, rendimientos de biomasa y contenido de clorofila $a$ y ficocianina en A. maxima crecida en los medios preparados en agua de mar que en el medio mineral estándar SOT. La diferencia mayor entre el medio SOT y los otros medios es la salinidad, aunque la concentración de algunos otros componentes incluyendo nutrientes esenciales $\left(\mathrm{HCO}_{3}, \mathrm{CO}_{3}, \mathrm{~N}, \mathrm{P}\right.$, $\mathrm{Fe})$ también es diferente.

Entre los tres medios preparados en agua de mar, la tasa de crecimiento y la biomasa fue menor en SWMAB, que es idéntico a SWM pero incluye varios elementos esenciales conocidos ( $\mathrm{Zn}, \mathrm{Cu}, \mathrm{Mo}, \mathrm{Mn})$, así como otros elementos cuya función en el fitoplancton no ha sido descrita. Posiblemente, el crecimiento pobre en este medio es el resultado de la toxicidad de metales que se adicionan en exceso. También es curioso que el crecimiento en SWMX2, el cual tiene el doble de contenido de $\mathrm{NaHCO}_{3}$, N, P y FeEDTA de SWM, no fue significativamente superior, lo que sugiere que el crecimiento permanece limitado por alguno de estos nutrientes o que la salinidad fue el factor más limitante. 
There are two differences between the SOT medium and seawater-based media: (i) salinity in the SOT medium is only above $1 / 3$ of the salinity of seawater used in our experiments; and (ii) $\mathrm{Cl}^{-}$is the major component in seawater, whereas this ion is less than $5 \%$ in the SOT medium. High $\mathrm{Cl}^{-}$concentrations were found to inhibit the external activity of carbonic anhydrase (Dionisio-Sese and Miyachi, 1992). However, A. maxima has shown to be resistant to high salinity stress (Tredici et al., 1986). If the culture were under osmotic or salinity stress, one would expect carotenoid concentrations to increase in the seawater cultures relative to SOT, which is not seen in our data. Ratios among carotenoid contents and chlorophyll $a$ contents (carot/chl $a$ ) increased in the seawater media as compared to the SOT medium culture, possibly as a response of protection to salinity stress.

In seawater cultures the $\mathrm{pH}$ values should be lower than 9 to avoid $\mathrm{NaCl}$ precipitation. This can be achieved by bubbling $\mathrm{CO}_{2}$; however, $\mathrm{CO}_{2}(1 \%)$ addition or any other addition should be programmed every day in small quantities since Gordillo et al. (1998) have reported pigment reduction using $\mathrm{CO}_{2}$ bubbling. This is the reason why bubbling withair rather than with $\mathrm{CO}_{2}$ was used in our study.

Phycobiliprotein content in A. maxima has an important role in the harvesting of light at low irradiance (Tomaselli et al., 1997). However, high salinity stress affects light utilization by depressing pigment synthesis and decreasing phycocyanin accumulation due to the low concentration of $\mathrm{NO}_{3}$ available in the media. The significantly lower phycocyanin content in the SWMX2 medium is difficult to explain. It is not likely because of $\mathrm{N}, \mathrm{P}$ or $\mathrm{Fe}$ limitation on this medium that contains twice the amount of these nutrients compared to the SWMAB and SWM media. Although the decrease in pigmentation is a response to the
Tredici et al. (1986) aseguran que el estrés fisiológico inducido por los cultivos de Spirulina maxima en agua de mar se puede evidenciar por la reducción en la velocidad de síntesis de proteína, un incremento en el contenido de carbohidratos, la fragmentación masiva en las tricomonas y una fuerte reducción en el contenido de ficocianina. Sin embargo, la concentración de células no fue muy diferente a los valores obtenidos en cultivos en agua dulce.

La baja tasa de crecimiento obtenida en nuestros experimentos de medios en agua de mar puede deberse a la pérdida de energía respiratoria y excretoria para contrarrestar el estrés iónico y osmótico (Kebede, 1997). Bajo condiciones de alta iluminación, los carotenoides son usados por algunas microalgas para proteger la clorofila $a$ de la fotooxidación, pero la síntesis de carotenoides también ha sido descrita como una respuesta a alta salinidad (Kebede, 1997). Hay dos diferencias entre el medio SOT y el medio con agua de mar: (i) la salinidad en el medio SOT está por debajo de $1 / 3$ de la salinidad del agua de mar usada en nuestros experimentos; y (ii) $\mathrm{Cl}^{-}$es el componente mayoritario en el agua de mar, mientras que este ión es menos del 5\% en el medio SOT. Altas concentraciones de $\mathrm{Cl}^{-}$han sido encontradas como inhibidoras de la actividad de la anhidrasa carbónica externa (Dionisio-Sese y Miyachi, 1992). Sin embargo, A. maxima ha demostrado ser resistente a alto estrés salino (Tredici et al., 1986). Si el cultivo está bajo estrés osmótico o salino, uno puede esperar que la concentración de carotenoides tienda a incrementar en cultivos en agua de mar en relación con SOT, lo cual no ha sido observado en nuestros datos. La relación entre el contenido de carotenoides y clorofila $a(\operatorname{carot} / \mathrm{chl} a)$ aumenta en los medios con agua de mar comparados con los cultivos en medio SOT, posiblemente como una respuesta de protección al estrés salino. 
Ciencias Marinas, Vol. 26, No. 4, 2000

salt stress noted in cyanobacteria (Vonshak et al., 1996), phycocyanin production seems to be feasible using seawater-based media; nevertheless, further studies should be done in order to optimize production and to scale up the process.

\section{ACKNOWLEDGEMENTS}

Teresa Lamela received a fellowship from the Spanish Agency for International Cooperation Agencia Española de Cooperación Internacional) through the "Programa de incorporación de jóvenes recién doctorados españoles a universidades mexicanas".

\section{REFERENCES}

Benett, A. and Bogard, L. (1973). Complementary chromatic adaptation in filamentous blue-green algae Spirulina platensis. J. Cell Biol., 58: 419-435.

Boussiba, S. and Richmond, A.E. (1979). Isolation and characterization of phycocyanins from the blue-green alga Spirulina platensis. Arch. Microbiol., 120: 155-159.

Boussiba, S. and Richmond, A.E. (1980). C-phycocyanin as a storage protein in the bluegreen alga Spirulina platensis. Arch. Microbiol., 125: 143-147.

Cai, X., He, L., Jiang-Jialun, J., Xu, X. and Zheng, S.(1995). The experimental study of application of phycocyanin in cancer laser therapy. Chin. J. Mar Drugs Zhongguo Haiyang Yaowu, 14: 15-18.

Castenholz, R.W. (1994). Oxygenic photoautotrophic bacteria. In J.G. Holt, N.R. Krieg, P.H.A. Sneath, J.T. Staley and S.T. Williams (eds.), Bergey's Manual of Determinative Bacteriology. 9th ed. Wilkins Publishers, Baltimore, $393 \mathrm{pp}$.

Chapman, D.J. (1988). Quantitative analysis of pigments. In: C.S. Lobban, D.J. Chapman, B.P. Kremer (eds.), Experimental Phycology. Cambridge Univ. Press, New York, pp.93-110.
En cultivos en agua de mar los valores de $\mathrm{pH}$ deben de ser menores que 9 para evitar la precipitación de $\mathrm{NaCl}$. Esto se puede obtener burbujeando con $\mathrm{CO}_{2}$; sin embargo, la adición de $\mathrm{CO}_{2}(1 \%)$ o alguna otra adición debe programarse todos los días en pequeñas cantidades, ya que Gordillo et al. (1998) han reportado reducción de pigmentos usando burbujeo con $\mathrm{CO}_{2}$. Fue por esta razón que el burbujeo con aire mejor que con $\mathrm{CO}_{2}$ fue usado en nuestro estudio.

El contenido de ficobiliproteínas en $A$. maxima tiene un papel importante en la captación de luz a baja intensidad de luz (Tomaselli et al., 1997). Sin embargo, el estrés salino elevado afecta la utilización de luz bajando la síntesis de pigmentos y disminuyendo la acumulación de ficocianina debido a la baja concentración de $\mathrm{NO}_{3}$ disponible en el medio. El contenido de ficocianina significativamente menor en el medio SWMX2 es difícil de explicar. Es poco probable que resulte de la limitación de $\mathrm{N}, \mathrm{P}$ o Fe en este medio que tiene dos veces la cantidad de nutrientes comparado a los medios SWMAB y SWM. Aunque la disminución en la pigmentación es una respuesta al estrés salino en cianobacterias (Vonshak et al., 1996), la producción de ficocianina parece ser factible usando medios preparados en agua de mar; no obstante, deben realizarse estudios futuros para optimizar la producción y el escalamiento del proceso.

\section{AGRADECIMIENTOS}

Teresa Lamela recibió apoyo de la Agencia Española de Cooperación Internacional mediante el "Programa de incorporación de jóvenes recién doctorados españoles a universidades mexicanas".

Traducido al español por los autores. 
Cysewski, G.R. (1992). Feeds, foods and pigments from Spirulina. J. Phycol., 28 (Suppl.): 12.

Dionisio-Sese, M.L. and Miyachi, S. (1992). The effect of sodium chloride on carbonic anhydrase activity in marine microalgae. J. Phycol., 28: 619-624.

Garnier, F. and Thomas, J.C. (1993). Light regulation of phycobiliproteins in Spirulina maxima. In: F. Doumenge, H. Durand-Chastel and A. Toulemont (eds.), Spirulina Algae of Life. Spirulina Algue de Vie. Monaco Musee Oceanographique NS (12): 41-48.

Gordillo, F.J.L., Jiménez, C., Figueroa, F.L. and Niell, F.X. (1998). Effects of increased atmospheric $\mathrm{CO}_{2}$ and $\mathrm{N}$ supply on photosynthesis, growth and cell composition of the cyanobacterium Spirulina platensis (Arthrospira). J.Appl. Phycol., 10: 461-469.

Herrera, A., Boussiba, S., Napoleone, V. and Hohlberg, A. (1989). Recovery of c-phycocyanin from the cyanobacterium Spirulina maxima. J. Appl. Phycol., 1: 325-331.

Kao, O.H.W., Berns, D.S. and Town, W.R. (1973). The characterization of $c$-phycocyanin from an extremely halotolerant blue-green alga Coccochloris elabens. Biochem. J., 131: 39-50.

Kebede, E. (1997). Response of Spirulina platensis (=Arthrospira fusiformis) from Lake Chitu, Ethiopia, to salinity stress from sodium salts. J.Appl. Phycol., 9: 551-558.

Márquez-Rocha, F.J. (1999). Reassessment of the bioenergetic yield of Arthrospira platensis using continuous culture. World J. Microbiol. Biotechnol., 15: 235-238.

Márquez, F.J., Sasaki, K., Nishio, N. and Nagai, S., (1995). Inhibitory effect of oxygen accumulation on the growth of Spirulina platensis. Biotechnol. Lett., 17: 225-228.

Materassi, R., Tredici, M. and Balloni, W. (1984). Spirulina culture in seawater. Appl. Microbiol. Biotechnol., 19: 384-386.
Miller, L.S. and Holt, S.C. (1977). Effect of carbon dioxide on pigment and membrane content in Synechococcus lividus. Arch. Microbiol., 115: 105-108.

Ogawa, T. and Terui, G. (1970). Studies on the growth of Spirulina platensis. I. On the pure culture of Spirulina platensis. J. Ferment. Technol., 48: 361-367.

Olguín, E.J., Hernández, B., Arus, A., Camacho, R., González, R., Ramírez, M.E., Galicia, S. and Mercado, G. (1994). Simultaneous high-biomass protein production and nutrient removal using Spirulina maxima in seawater supplemented with anaerobic effluents. World J. Microbiol. Biotechnol., 10: 576-578.

Olguín, E.J., Galicia, S., Camacho, R., Mercado, G. and Pérez, T.J. (1997). Production of Spirulina sp. in seawater supplemented with anaerobic effluents in outdoor raceways under temperate climatic conditions. Appl. Microbiol. Biotechnol., 48: 242-247.

Tandeu, M.N. and Houmard, J. (1988). Complementary chromatic adaptation: Physiological conditions and action spectra. Methods Enzymol., 167: 138-328.

Tomaselli, L., Boldrini, G. and Margheri, M.C. (1997). Physiological behavior of Arthrospira (Spirulina) maxima during acclimation to changes in irradiance. J. Appl. Phycol., 9: 37-43.

Tredici, M.R., Papuzzo, T. and Tomaselli, L. (1986). Outdoor mass culture of Spirulina maxima in seawater. Appl. Microbiol. Biotechnol., 24: 47-50.

Vonshak, A., Kancharaska, N., Bunnag, B. and Tanticharoen, M. (1996). Role of light and photosynthesis on the acclimation process of the cyanobacterium Spirulina platensis to salinity stress. J. Appl. Phycol., 8: 119-124.

Wu, B., Tseng, C.K. and Xiang, W. (1993). Largescale cultivation of Spirulina in seawater-based culture medium. Bot. Mar., 36: 99-102. 